LETTER TO JMG

\title{
Short-limbed dwarfism with bowing, combined immune deficiency, and late onset aplastic anaemia caused by novel mutations in the RMPR gene
}

\author{
T W Kuiipers, M Ridanpää, M Peters, I de Boer, J M J J Vossen, S T Pals, I Kaitila, R C M Hennekam
}

J Med Genet 2003;40:761-766

$\mathrm{K}$ phomelic dysplasia has been described as a generalised skeletal dysplasia characterised by a disproportionate growth, bowing of long bones, mild facial dysmorphia, and normal intelligence, with radiologically flattened vertebrae, short ribs, and metaphyseal flaring. Twenty-one cases have been reported in the literature. ${ }^{1-14}$ However the diagnosis in several cases from the literature has been disputed. The case described by Maclean and co-workers ${ }^{10}$ was reported recently to have Schwartz-Jampel syndrome, ${ }^{15}$ and the family reported by Toledo et $a l^{5}$ in fact had osteogenesis imperfecta. This led Spranger et al ${ }^{15}$ to suggest that kyphomelic dysplasia does not exist. However, there is still a group of cases described as kyphomelic dysplasia, which do not fit the profile of these or other disorders that manifest as dwarfism and kyphomelia. ${ }^{16}$ The cases can be distinguished from campomelic dysplasia by the extraskeletal manifestations, mental retardation, ambiguous genitalia, severe tibial bowing, and hypoplastic scapulae in the latter, ${ }^{17}$ and from femoral hypoplasia-unusual facies syndrome by the hypoplasia of the femur. ${ }^{18}$ Several single case reports that show a related but still different phenotype have been described. ${ }^{19-21}$

Short-limbed dwarfism with normal intelligence does also occur in cartilage-hair hypoplasia (CHH; MIM 250250). Apart from dwarfism, major symptoms include fine, sparse hair, marked hypermobility of the smaller joints with short phalanges, and a variable immunodeficiency. ${ }^{22}$ Radiologically, the metaphyses are scalloped and sclerotic, especially around the knees, ankles, and anterior angulation of the entire sternum. The femur can be bowed, but usually only mildly so. There is no platyspondyly. $\mathrm{CHH}$ presenting in infancy can be difficult to diagnose. ${ }^{23}{ }^{24}$ Mutations in the RMRP gene that codes for an RNA subunit of the mitochondrial RNA processing (MRP) RNAse complexes are the cause of $\mathrm{CHH}$, with a common "Finnish" mutation $+70 \mathrm{~A} \rightarrow \mathrm{G}(\mathrm{A} 70 \mathrm{G})$ in many of the known $\mathrm{CHH}$ patients..$^{25} 26$

Here we report on a case with short-limb dwarfism diagnosed as having kyphomelic dysplasia in infancy, who developed severe aplastic anaemia, concurring with a combined immune deficiency of late onset. She received a successful allogeneic bone marrow transplant. The phenotype gradually changed and became more typical of $\mathrm{CHH}$. Mutation analysis subsequently showed two novel mutations in the $R M R P$ gene.

\section{METHODS}

Immunological studies

Lymphocyte phenotyping

Absolute numbers of $\mathrm{B}$ cell (CD19+), $\mathrm{T}$ cell (CD2+, CD3+, CD4+, CD8+), and NK cell (CD3-, CD16+, CD56+) subsets were determined by standard FACScan procedures, with MAbs being produced by the Central Laboratory of the Netherlands Red Cross Blood Transfusion Service. CD3, CD4,

\section{Key points}

- A female patient was diagnosed with kyphomelic dysplasia in infancy, because of her short limbed dwarfism and kyphomelia, especially of the femurs.

- She developed a combined aplastic anaemia and immunodeficiency of late onset that responded well to allogeneic bone marrow transplantation, although growth remained extremely retarded.

- Clinical and radiological symptoms gradually changed and became more typical for cartilage-hair hypoplasia, as was confirmed by two novel mutations in the RMRP gene (insT195/C63T).

- Kyphomelic dysplasia constitutes a heterogeneous group of different disorders, which includes cartilagehair hypoplasia.

CD8, CD19, TcR $\alpha \beta$ and TcR $\gamma \delta$ MAbs conjugated with FITC and PerCP were all purchased from Becton-Dickinson (San Jose, CA, USA). Using PE conjugated CD45RA and CD45RO MAbs from Coulter Immunology (Haleah, FL, USA) for staining, gating on CD3+ lymphocytes allowed further subtyping into functional CD4+ and CD8+ T cell subpopulations, and naive and memory cells, respectively). After lysing the erythrocytes, lymphocytes were fixated using Cellfix (BectonDickinson) and analysed on a FACScan (Becton-Dickinson) with Cellquest software, using a lymphocyte gate. ${ }^{27}$

\section{Histochemistry}

Histochemistry and immunophenotypical analysis of the thymus and lymph nodes was carried out with the use of standard staining procedures and a streptavidin-biotin complex method on paraffin embedded sections, and a three step indirect immunoperoxidase method with AEC as a substrate on frozen sections. Primary antibodies used were CD3 (pan T cell), CD4 and CD8 for T cells (thymocytes and mature $\mathrm{T}$ helper cells/cytotoxic T cells), CD68 (pan macrophage), CD20 and CD79A (mature B cells), CD25 (IL-2R $\alpha$, thymocytes and activation of mature T cells), Ki67 (proliferating cells) and immunoglobulin heavy chains (IgA, IgM and IgG).

\section{Molecular studies}

Genomic DNA from a fibroblast cell line established from the patient's cells was extracted using standard methods. The

Abbreviations: $\mathrm{BMT}$, bone marrow transplantation; $\mathrm{CHH}$, cartilagehair hypoplasia; MRP, mitochondrial RNA processing 
whole RNA coding region of RMRP (Genbank accession number M29916) was amplified in two separate PCRs using primers RMF 5'-CCAACTTTCTCACCCTAACCA-3' and RMR 5'-AAGGCCAAGAACAGCGTAAA-3'. PCR products were run on $1 \%$ SeaKem (FMC BioProducts) gels, purified using Qiagen Gel Extraction Kit (Qiagen, Valencia, USA) and sequenced automatically (ABI3100; Applied Biosystems, Foster City, LA, USA).

\section{CLINICAL REPORT}

The proband is the first child of a non-consanguineous couple, with no family history of congenital abnormalities. Her 26 year old mother is white and her 39 year old father is of African-American descent; both are healthy. She has a healthy younger brother. Intrauterine growth retardation was observed from the 24th week of gestation. Ultrasound examination showed skeletal abnormalities, including shortening and bowing of the limbs. Campomelic dysplasia was suspected. The girl was born by vaginal delivery after 40 weeks and 4 days gestation, birth weight $2790 \mathrm{~g}$ (10th percentile), length $38 \mathrm{~cm}$ (<3rd percentile), OFC $35 \mathrm{~cm}$ (10th percentile). APGAR scores after 1 and 5 min were 9 and 10, respectively. Physical examination showed abnormal, short, curved limbs, most striking in the femur, and a small chest. Hands and feet appeared normal at that time. Radiographs showed short, flared ribs, vertebral flattening, and bowed femur, humerus, tibia and radius. No firm diagnosis was made at that time. The child was re-evaluated at 1 year of age, when the diagnosis of kyphomelic dysplasia was made (figs $1 \mathrm{~A}$ and $\mathrm{B}$ ).

During the first 2 years, she suffered from recurrent upper respiratory infections and diarrhoea, twice necessitating admittance. She recovered following rehydration and antibiotics. Laboratory findings were normal at that time.

At the age of 2 years and 5 months, she was admitted for the third time because of loss of appetite while having chronic diarrhoea. There were no signs of infections or haemorrhagic diathesis. Examination on admission showed a pale, dystrophic and tachypnoeic girl (fig 2), with a weight of $7.3 \mathrm{~kg}$ (percentile \pm 4SD) and a height of $60 \mathrm{~cm}$ (percentile $\pm 4 \mathrm{SD}$ ). Tonsils were present; lymph nodes were not enlarged. There was hepatomegaly in the absence of splenomegaly or clinical jaundice. Haematological studies were compatible with aplastic anaemia, as described in table 1 . No proof for a recent (viral) infection was obtained. Bone marrow was hypocellular without erythropoiesis, and the myeloid lineage was hypoplastic; number and morphology of megakaryocytes was normal. Clonal derangements or myelodysplastia were excluded by morphology, immunophenotyping, and cytogenetic studies for chromosomal abnormalities ( such as monosomy 7); the chromosomes were 46XX.

Immunological studies showed defects as described in table 1. Lymphocyte proliferation tests were severely impaired upon activation with mitogens or combined CD3/ CD28 receptor signalling (not shown). A normal sized thymus was present on computerised tomography scanning. Pathological studies showed a hypocellular biopsy specimen lacking Hassal's bodies (fig 3A). Lymph node biopsy showed hypocellularity with depleted T cell areas, and some follicular structures with extremely small numbers of IgA and IgG positive plasma cells (fig 3B). It was concluded that the patient had a combined immune deficiency of late onset. An infection was ruled unlikely because of negative microbiological cultures and PCR tests for several viruses (cytomegalovirus, Epstein-Barr virus, HIV, parvovirus B19) in nose washings, faeces, urine, blood, and bone marrow.

The patient had borderline malabsorption, as indicated by the low serum levels of fat soluble vitamins A and E $(0.7$ $\mathrm{nmol} / \mathrm{L}$ and $7.3 \mathrm{~mol} / \mathrm{L}$, respectively). However, $25 \mathrm{OH}$-vitamin
A
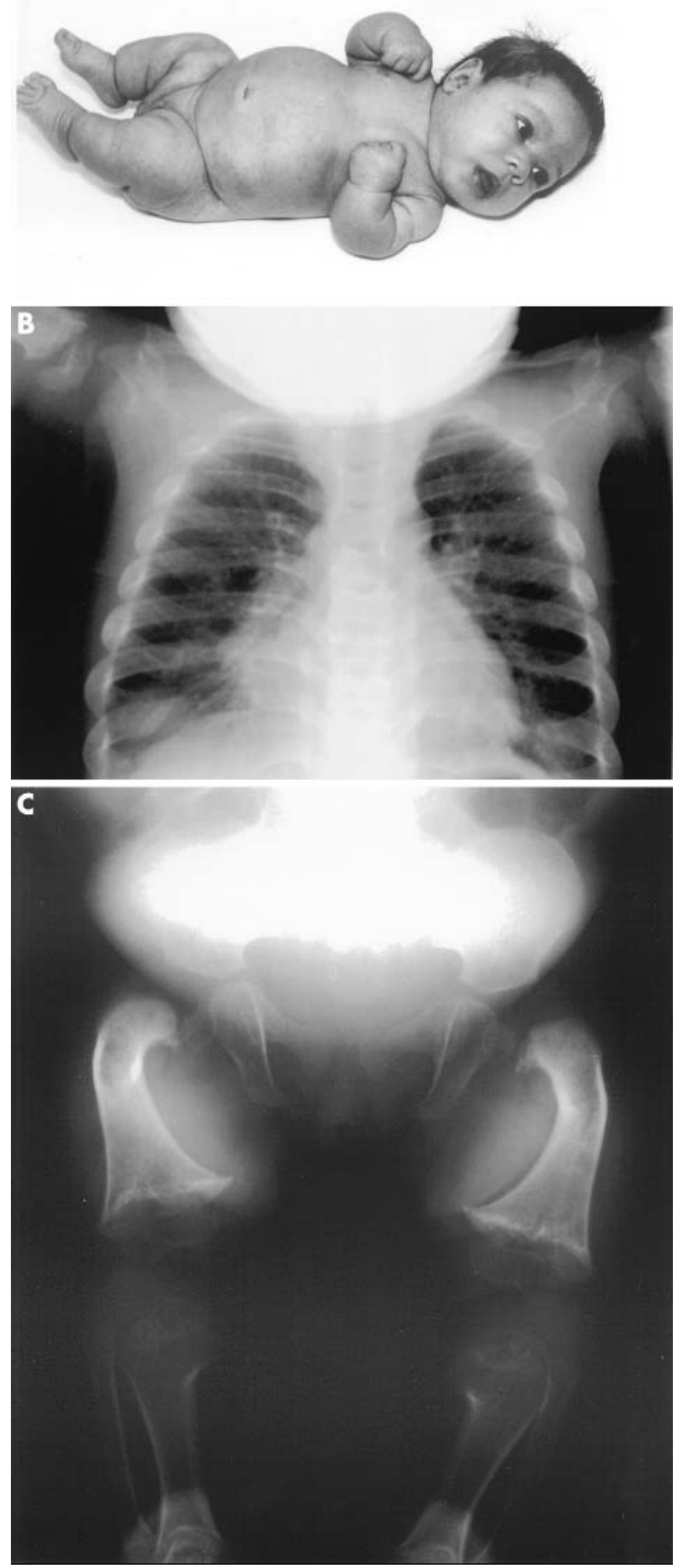

Figure 1 (A) Clinical phenotype of the propositus at the age of 3 months, and radiographs of $(B)$ thorax of the proband at age 6 months, and $(C)$ pelvis and femur at age 2 years. Note the small chest, short ribs with flared ends, short and severely bowed femur, underossification of proximal tibia, and increased acetabular angles.

D was normal $(21 \mathrm{nmol} / \mathrm{L})$, as were the levels of water soluble folic acid and vitamin $\mathrm{B}_{12}$. From stool collection over $72 \mathrm{hrs}$, the fat absorption coefficient was calculated at $85 \%$ (low-normal), with unaltered pancreatic function as demonstrated by normal levels of faecal chymotrypsin $(3.0 \mathrm{~g} / \mathrm{g}$ faeces), and serum amylase and lipase. Faeces were negative 


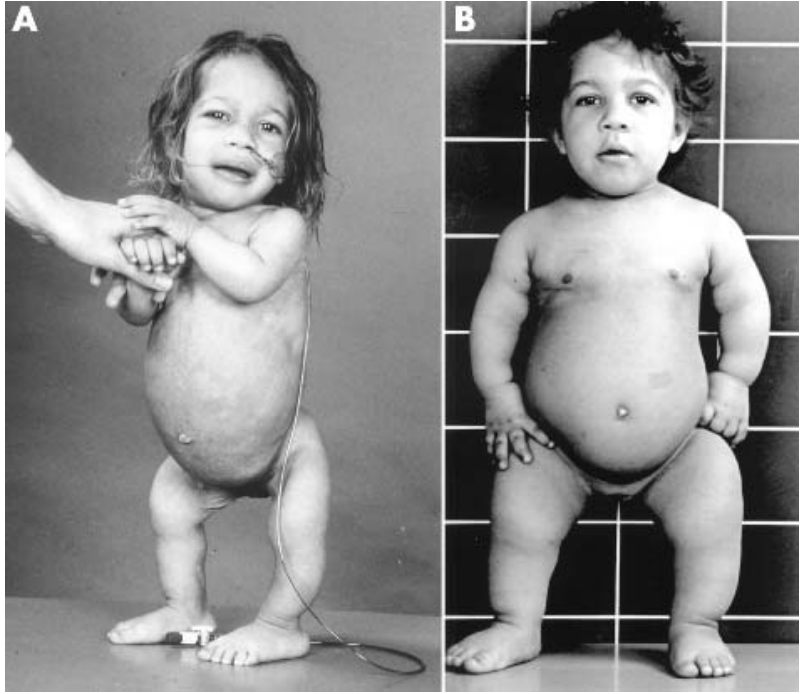

Figure 2 Clinical pictures of the propositus during development, at the age of (A) 2 years (prior to bone marrow transplantation (BMT)); and (B) 4 years ( 1 year post-BMT).

for known pathogens, in particular Giardia, Cryptosporidium, and microsporidial species. Duodenal biopsies did not reveal any abnormality (such as mucosal flattening or absence of mucosal/intraepithelial lymphocytes). Liver and kidney functions were normal as determined by plasma levels of bilirubin, ALAT, ASAT, and creatinine. However, alkaline phosphatase, which had been normal at birth, fluctuated between 7000 and $11000 \mathrm{U} / \mathrm{L}$ in the presence of normal levels of parathormone $(2.8 \mathrm{pmol} / \mathrm{L})$, calcitonine $(0.14 \mathrm{~g} / \mathrm{L})$, serum calcium $(2.30 \mathrm{mmol} / \mathrm{L})$ and phosphate $(1.85 \mathrm{mmol} / \mathrm{L})$. Further endocrinological studies excluded any defect in thyroid function or the GH/IGF-1 or hypothalamo-pituitaryadrenal axis.

At 3 years of age the patient was referred for allogeneic bone marrow transplantation (BMT) from her HLA identical brother. The conditioning regimen consisted of busulphan $(20 \mathrm{mg} / \mathrm{kg}$ total dose) on days -9 to -6 and cyclophosphamide $(200 \mathrm{mg} / \mathrm{kg} /$ dose $)$ on days -5 to -2 . The patient received $2.5 \times 10^{8}$ nucleated cells/kg (recipient body weight). Graft $v$ host disease prophylaxis consisted of methotrexate on day $+1,+3$, and +6 and ciclosporin A from day -1 to +180 . Post-transplantation supportive care consisted of total gastrointestinal decontamination in a strict protective (sterile) environment. Haematological engraftment was achieved on day +17 ; platelet transfusion independence on day +28 . One day later, she was discharged. At 6 months posttransplantation, complete immunological engraftment, with normal $\mathrm{T}$ and $\mathrm{B}$ cell function, was present. Donor chimerism was complete. She has recently had chickenpox, as has her healthy brother; her condition up to now is excellent without medication.

Her growth remained unaltered by the BMT. A biochemical decrease in alkaline phosphatase was seen during the preconditioning period, reaching normal levels at day +10 post-BMT. Bone age has a considerable lag of about 4 years. She was last evaluated at the age of 8 years. She had mild constipation treated with dietary regiments but did not need any medication. Growth and implantation of her hair was considered to be normal considering her ethnic descent. In addition, eyebrows, eyelashes, and nails were normal. She had a short thorax, mild asymmetric pectus carinatum, prominent abdomen caused by her expressed hyperlordosis, and mild scoliosis. There were three café-au-lait spots on her thorax. Her hands, fingers, feet, and toes had become much
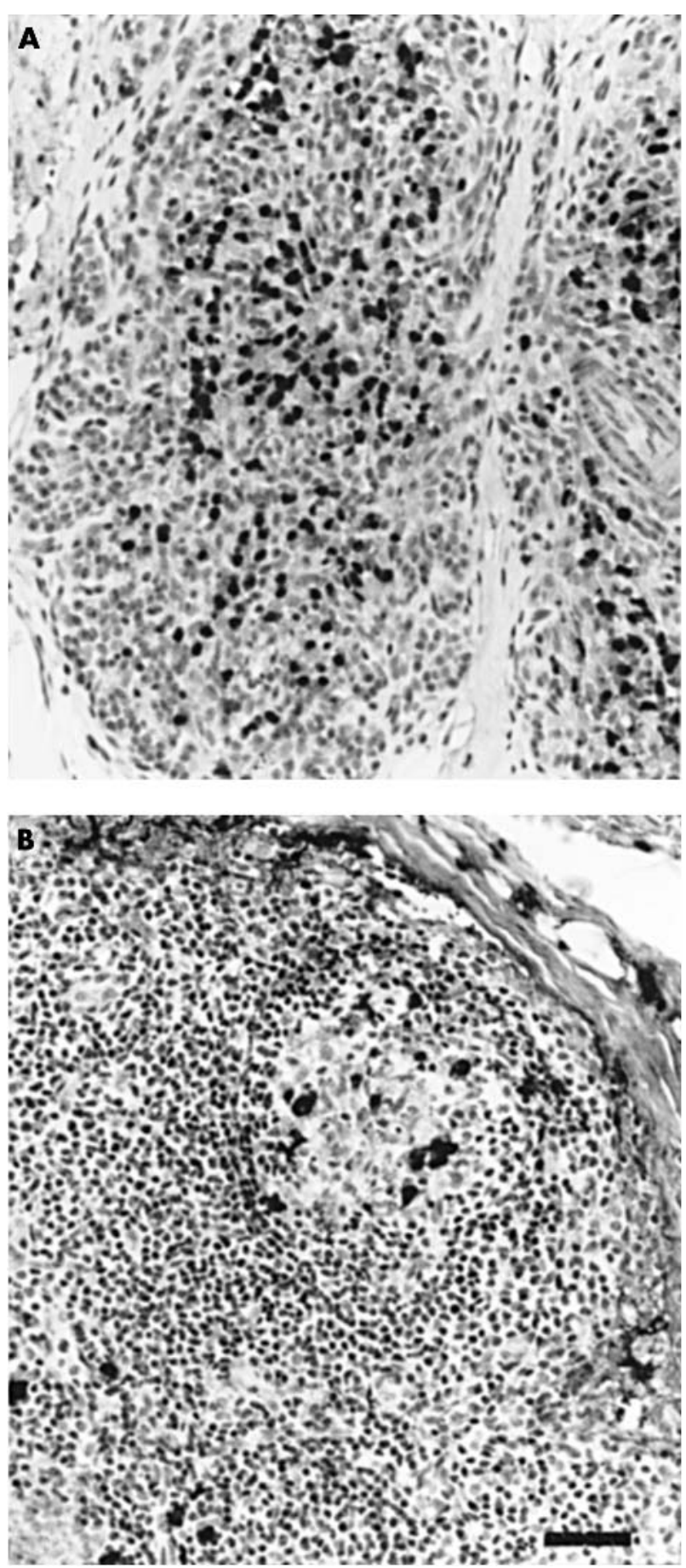

Figure 3 Immunohistochemistry of thymus and mediastinal lymph node. (A) Thymus was stained with anti-TdT, showing a disturbed architecture with a loss of demarcation between the cortex and medulla, and scattered TdT positive cells in the central area of the thymic lobule. Hassal's bodies were absent. (B) Lymph node was stained with anti-lgG, showing a partial lymphocyte depletion of the paracortical areas, which were small and contained only a few CD3 positive T cells. Several small germinal centres (GC) were present, as shown here (top right position). Dark dots in the GC and medullary area represent lgG expressing plasma cells. Counterstained with hematoxylin. Bar $=0.1 \mathrm{~mm}$.

shortened compared with earlier ages. Joint mobility was normal. The upper arms were mildly bowed, the upper legs were severely bowed. Radiologically, she had expressed metaphyseal widening and sclerosis, especially in the upper femur, and around the knees and ankles. The metaphyses 
showed cystic radiolucencies, especially around the knees and ankles. There was mild bowing of the humerus and tibia, and extensive bowing of the femur. The tibia was larger than the fibula. The height of the vertebral bodies was normal, as was the caudal widening of the interpediculate distances. The hand radiographs now showed short phalanges and metacarpals, sclerotic epiphyses of the distal phalanges, cupped epiphyses of all middle phalanges but not of the proximal phalanges, and irregular epiphyses and metaphyses of the distal radius and ulna.

Sequence analysis showed the patient to be compound heterozygous for two mutations in the transcript of $R M R P$. The first mutation was a base substitution of $\mathrm{T}$ for $\mathrm{C}$ at nucleotide 63. This mutation was previously found in one Australian $\mathrm{CHH}$ patient (unpublished results). The other mutation was a novel duplication of T at nucleotide 195. Both mutations resided in evolutionarily conserved nucleotides ${ }^{29}$ and were not found in healthy controls. Molecular studies in the parents showed the father to have the insT195 and the mother to have the C63T mutation. Thus, molecular gene analysis to verify for $\mathrm{CHH}$ now demonstrated two novel mutations in the RMRP gene.

\section{DISCUSSION}

There are several short limb/skeletal dysplasias that can be associated with variable degrees of immune deficiency. ${ }^{21} 2228$ In the present case the diagnosis kyphomelic dysplasia was made at the age of 1 year because of the expressed bowing of the femur, the platyspondyly, and only mild metaphyseal dysplasia. With time, the shortening of the thorax, hands and feet, metaphyseal changes especially around the knees, cystic radiolucencies, and normal height of the vertebral bodies became clear, all pointing to CHH. However, several other symptoms usually present in $\mathrm{CHH}$, such as fine hair, hypermobility of the finger joints, nail anomalies, or short tibia were not present, while the femoral bowing was unusually severe. The mutations in the $R M R P$ gene proved that $\mathrm{CHH}$ was the correct diagnosis.

Some of the earlier reports on cases diagnosed as kyphomelic dysplasia or reminiscent of the diagnosis may have been $\mathrm{CHH}$ instead, as they demonstrated haematological defects, a clear cut immunodeficiency, or mortality at an early age caused by infection. ${ }^{13} 11{ }^{1921}$ Molecular studies for mutations in the RMRP gene in other cases diagnosed as kyphomelic dysplasia are essential, as are careful analyses for other, similar entities (for instance, plasma levels of alkaline phosphatase and molecular studies of collagen type I mutations for hypophosphatasia and osteogenesis imperfecta, respectively). It remains uncertain whether all cases described as having kyphomelic dysplasia will be found to have symptoms fitting other known entities, or whether it will be confirmed as a separate entity characterised by shortlimbed dwarfism and kyphomelia.

The present case suffered from a highly unusual form of aplastic anaemia and combined immune deficiency, both of a late onset type, without the typical red cell abnormalities usually observed in $\mathrm{CHH}^{29}$ The immune defect was most notable in her $\mathrm{T}$ cell compartment, similar to the immune defect most commonly found in CHH. ${ }^{22} 3031$ Under normal conditions, the thymus generates sufficient numbers of naive CD45RA+ T lymphocytes (both CD4+ and CD8+) for early development and continuous maintenance of the immune system to enable the host to respond to newly encountered antigens during life. ${ }^{32}$ In this patient, thymic output had been progressively lost. First, circulating naive CD45RA+ T cells were no longer present. Secondly, the ability to show a memory response to tetanus toxoid by the remaining CD45RO+ T cells and B cells was still intact, but the ability to respond to a so-called primary or neo-antigen, keyhole limpet antigen ( $K L H$; see table 1$)$, was completely absent. The exhaustion of the thymic function was further indicated by a specimen of the thymus, showing a complete absence of the so-called Hassal's bodies (fig. 3A). The normal size argues against a primary thymus dysplasia in our patient. Moreover, complete restoration upon HLA identical allogeneic BMT is further support for a normal thymus anlage and function. To our knowledge, these findings have not been reported previously in $\mathrm{CHH}$.

The patient's haematological and immunological course is highly unusual for its late onset. The symptoms could be

\begin{tabular}{|c|c|c|c|c|c|c|}
\hline Hematology & Birth & 1 year & 2 years & $2 \frac{1}{2}$ years & $\begin{array}{l}3 \text { years (BMT } \\
+5 \text { days) }\end{array}$ & $\begin{array}{l}5 \text { years (BMT } \\
+2 \text { years) }\end{array}$ \\
\hline $\mathrm{Hb}(\mathrm{g} / \mathrm{dL})$ & 15.9 & - & $9.5^{*}$ & $2.0^{*}$ & $6.8 \dagger$ & 13.1 \\
\hline $\mathrm{Ht}(\mathrm{L} / \mathrm{L})$ & 0.53 & - & 0.33 & $0.07^{*}$ & - & 0.40 \\
\hline Reticulocytes $\left(10^{6} / \mathrm{mL}\right)$ & NT & - & 3.2 & $<0.1^{*}$ & - & 2.1 \\
\hline$M C V(f L)$ & NT & - & 90 & 79 & - & 83.7 \\
\hline Platelets $\left(10^{6} / \mathrm{mL}\right)$ & 134 & - & 150 & 483 & $20+$ & 379 \\
\hline Leukocytes $\left(10^{6} / \mathrm{mL}\right)$ & 18.9 & - & 9.4 & $1.1^{*}$ & 0.1 & 8.1 \\
\hline$\%$ neutrophils & 68 & - & 52 & 22 & - & 52 \\
\hline$\%$ monocytes & 6 & - & 10 & 8 & - & 6 \\
\hline \% lymphocytes & 22 & - & 35 & 67 & - & 42 \\
\hline $\lg G$ & - & 11.5 & 9.6 & 5.2 & - & 11.3 \\
\hline $\lg A$ & - & 1.4 & 1.0 & 0.4 & - & 1.4 \\
\hline $\lg M$ & - & 1.0 & 0.7 & $0.3^{*}$ & - & 1.3 \\
\hline Lymphocytes $\left(10^{6} / \mathrm{mL}\right)$ & - & 4.2 & 3.3 & $0.7^{*}$ & - & 3.4 \\
\hline CD3+ T cells & - & - & - & $0.3^{*}$ & - & 1.9 \\
\hline TcR $\alpha \beta$ & - & - & - & $51 \%$ & - & - \\
\hline $\operatorname{TcR} \gamma \delta$ & - & - & - & $49 \%$ & - & - \\
\hline $\mathrm{CD} 3+/ 4+$ Th cells & - & - & - & $0.06^{*}$ & - & 1.03 \\
\hline CD45RA & - & - & - & $7 \%$ & - & $81 \%$ \\
\hline CD45RO & - & - & - & $84 \%$ & - & $22 \%$ \\
\hline $\mathrm{CD} 3+/ 8+\mathrm{Tc}$ cells & - & - & - & $0.1^{*}$ & - & 0.74 \\
\hline CD45RA & - & - & - & $56 \%$ & - & $85 \%$ \\
\hline CD45RO & - & - & - & $42 \%$ & - & $14 \%$ \\
\hline CD19+ B cells & - & - & - & 0.2 & - & 1.11 \\
\hline CD16/56+NK cells & - & - & - & 0.2 & - & 0.34 \\
\hline
\end{tabular}


compatible with a dramatic change at the level of the haematopoietic stem cell, resulting in a developmental arrest in all lineages, including the $\mathrm{T}$ cell development in the thymus. Megakaryocytic development was spared, and platelet counts in the blood remained relatively normal. Although unexplained, this phenomenon suggests that the bone marrow stroma was unaffected by the disease.

Although several examples of murine models for late onset disease exist, they do not show a clear homology to the underlying disease in our patient. ${ }^{33-35}$ The endoribonuclease RNase MRP consists of an RNA molecule bound to several proteins. It has at least two functions, namely, cleavage of RNA in mitochondrial DNA synthesis and nucleolar cleaving of pre-rRNA. ${ }^{36}$ A role of RNase MRP in cell cycle progression at the end of mitosis has been suggested to explain several of the $\mathrm{CHH}$ symptoms. ${ }^{37}$ However, the late onset appearance in our patient is difficult to reconcile with this hypothesis. A clear phenotype-genotype relationship seems absent in $\mathrm{CHH}$. Variation in clinical severity is wide, even within affected families. Only heterozygosity of insertion and duplication mutations has been detected, suggesting that expression of the RNA molecule is essential for life. To date, no mutations have been found in nucleotides $23-62$, which were reported to be a nucleolar localisation region. ${ }^{26}$ Whether the phenotype depends on the most proximal and novel C63T mutation is as yet unclear.

In our patient, blood levels of alkaline phosphatase began to decline upon total decontamination of the digestive tract, followed by a complete normalisation within the first week after allogenic BMT. Liver function has always remained normal. If indeed derived from bone, AP represents a maturation marker of osteoblasts. The interplay between osteoblasts and activated osteoclasts may have been disturbed for some time in our patient, until a change in the bacterial flora reset the increased serum levels of AP. The levels of AP remained low.

Stem cell transplantation has been used for several bone diseases such as osteogenesis imperfecta and forms of malignant osteopetrosis. ${ }^{39-42}$ The bone dysplasia in our patient did not improve upon BMT, as has been observed before in $\mathrm{CHH}^{28}{ }^{43}$

In conclusion, the female patient with short-limb dwarfism presented here shows an unusual late onset haematological and immunological disorder. Recessive metaphyseal dysplasia without hypotrichosis (MIM 250460), a disorder presenting with short stature and metaphyseal dysplasia similar to $\mathrm{CHH}$, but lacking hair anomalies, immunodeficiency and other extra skeletal features, was recently suggested to be allelic to $\mathrm{CHH}^{44}$ In our patient, the early presentation was most compatible with kyphomelic dysplasia, but later $\mathrm{CHH}$ became more likely, and was proven by the mutated RMRP gene. The neonatal presentation and the immunological characteristics of $\mathrm{CHH}$ are therefore even more variable than earlier thought. ${ }^{24}$

\section{Authors' affiliations}

T W Kuijpers, M Peters, R C M Hennekam, Emma Children's Hospital, Academic Medical Center (AMC), Amsterdam, The Netherlands M Ridanpää, I Kaitila, Department of Human Genetics, University of Helsinki, Helsinki, Finland

I de Boer, J M J J Vossen, Leiden University Medical Center (LUMC), Kinder-en Jeugdcentrum, Leiden, The Netherlands

S T Pals, Department of Pathology, AMC, Amsterdam, The Netherlands R C M Hennekam, Department of Clinical Genetics, Institute of Human Genetics, AMC, Amsterdam, The Netherlands

Correspondence to: TW Kuijpers, Emma Children's Hospital, Academic Medical Center (G8-205), Meibergdreef 9, 1105 AZ Amsterdam, The Netherlands; t.w.kuijpers@amc.uva.nl

\section{REFERENCES}

1 Turnpenny PD, Dakwar RA, Boulos FN. Kyphomelic dysplasia: the first 10 cases. J Med Genet 1990;27:269-72.

2 Maffulli N, Blakeway C, Fixsen JA. Long-term follow up of a case of kyphomelic dysplasia. Orthopedics 1993;16:86-9.

3 Corder WT, Hummel M, Miller C, Wilson NW. Association of kyphomelic dysplasia with severe combined immunodeficiency. Am J Med Genet 1995;57:626-9.

4 Chen CP, Chern SR, Shih SL, Chuang CY, Huang FY. Kyphomelic dysplasia in two sib fetuses. J Med Genet 1998;35:65-9.

5 Toledo C, Navarro-Barros R, Alba L, Munoz E. Kyphomelic dysplasia: a report of a family with an autosomal dominant pattern. Ann Genet 1999:42:170-3.

6 Pallotta R, Ehresmann T, Roggini M, Fusilli P. Kyphomelic dysplasia: clinical and radiologic long-term follow-up of one case and review of the literature. Radiology 1999;212:847-52.

7 Cisarik F, Kozlowski K, Masel J, Sillence D. Variability in kyphomelic dysplasia. Pediatr Radiol 1999;29:551-7.

8 Hall BD, Spranger JW. Familial congenital bowing with short bones. Radiology 1975;132:611-14.

9 Khajavi A, Lachman R, Rimoin D, Schimke RN, Dorst J, Handmaker S Ebbin A, Perrault G. Heterogeneity in the campomelic syndromes. Radiology 1996;120:641-7.

10 Maclean RN, Prater WK, Lozzio CB. Skeletal dysplasia with short, angulated femora (kyphomelic dysplasia). Am J Med Genet 1993;14:373-80.

11 Rezza E, lannaccone G, Lendvai D. Familial congenital bowing with short thick bones and metaphyseal changes, a distinct entity. Pediatr Radiol 1984; 14:323-7.

12 Temple IK, Thompson EM, Hall CM, Bridgeman G, Pembrey ME. Kyphomelic dysplasia. J Med Genet 1989;26:457-68.

13 Vilioen D, Beighton P. Kyphomelic dysplasia: further delineation of the phenotype. Dysm Clin Genet 1988;1:136-41

14 O'Reilly MAR, Hall CM. Kyphomelic dysplasia. J Med Genet 1994;31:423-7.

15 Spranger J, Hall BD, Hane B, Srivastava A, Stevenson RE. Spectrum of Schwartz-Jampel syndrome includes micromelic chondrodysplasia, kyphomelic dysplasia, and Burton disease. Am J Med Genet 2000:94:287-95.

16 Gorlin RJ, Cohen MM, Hennekam RCM. Syndromes of the head and neck New York: Oxford University Press, 4th ed, 2001.

17 Mortier GR, Rimoin DL, Lachman RS. The scapula as a window to the diagnosis of skeletal dysplasias. Pediatr Radiol 1997;27:247-51.

18 Pitt D. Kyphomelic dysplasia versus femoral hypoplasia - unusual facies syndrome. Am J Med Genet 1986;24:365-6.

19 Moore LA, Moore CA, Smith JA, Weaver DD. Semi-lethal bone dysplasia in three sibs: a new genetic disorder. Clin Genet 1984;26:249-51.

20 Moore LA, Moore CA, Smith JA, Weaver DD. Asymmetric and symmetric long bone bowing in two sibs: an apparently new bone dysplasia. Am J Med Genet 1993:47:1072-7.

21 MacDermot KD, Winter RM, Wigglesworth JS, Strobel S. Short stature/short limb skeletal dysplasia with severe combined immunodeficiency and bowing of the femora: report of two patients and review. J Med Genet 1991:28:10-17.

22 Mäkitie O, Kaitila I. Cartilage-hair hypoplasia-clinical manifestations in 108 Finnish patients. Eur J Pediatr 1993;152:211-17.

23 Glass RB, Tifft CJ. Radiologic changes in infancy in McKusick cartilage hair hypoplasia. Am J Med Genet 1999:86:312-15.

24 Le Merrer M, Maroteaux P. Cartilage-hair hypoplasia in infancy: a misleading chondrodysplasia. Eur J Pediatr 1991;150:847-51.

25 Ridanpaa M, van Eenennaam H, Pelin K, Chadwick R, Johnson C, Yuan B, vanVenrooii W, Pruijn G, Salmela R, Rockas S, Makitie O, Kaitila I, de la Chapelle A. Mutations in the RNA component of RNase MRP cause a pleiotropic human disease, cartilage-hair hypoplasia. Cell 2001; 104: 195-203.

26 Ridanpaa M, Sistonen P, Rockas S, Rimoin DL, Makitie O, Kaitila I. Worldwide mutation spectrum in cartilage-hair hypoplasia: ancient founder origin of the major $70 \mathrm{~A} \rightarrow \mathrm{G}$ mutation of the untranslated RMRP. Eur J Hum Genet 2002; 10:439-47

27 Hamann D, Baars PA, Rep MH, Hooibrink B, Kerkhof-Garde SR, Klein MR van Lier RA. Phenotypic and functional separation of memory and effector human CD8+ T cells. J Exp Med 1997;186:1407-18.

28 Hong R. Associations of the skeletal and immune systems. Am J Med Genet 1989:34:55-9.

29 Mäkitie O, Rajantie J, Kaitila I. Anaemia and macrocytosis-unrecognized features in cartilage-hair hypoplasia. Acta Paediatr 1992;81:1026-9.

30 Mäkitie O, Kaitila I, Savilahti E. Susceptibility to infections and in vitro immune functions in cartilage-hair hypoplasia. Eur J Pediatr 1998;157:816-20.

31 Kooijman R, van der Burgt CJ, Weemaes CM, Haraldsson A, Scholtens EJ, Zegers BJ. T cell subsets and T cell function in cartilage-hair hypoplasia. Scand J Immunol 1997;46:209-15.

32 George AJT, Ritter MA. Thymic involution with ageing: obsolescence or good housekeeping? Immunol Today 1996;17:267-71.

33 Clevers HC, Grosschedl R. Transcriptional control of lymphoid development: lessons from gene targeting. Immunol Today 1996;17:336-43.

34 Reimold AM, Grusby MJ, Kosaras B, Fries JW, Mori R, Maniwa S, Clauss IM Collins T, Sidman RL, Glimcher MJ, Glimcher $\mathrm{LH}$. Chondrodysplasia and neurological abnormalities in ATF2-deficient mice. Nature 1996;379:262-5.

35 Jacobs JJ, Kieboom K, Marino S, DePinho RA, van Lohuizen M. The oncogene and polycomb-group gene bmi-1 regulates cell proliferation and senescence through the ink4a locus. Nature 1999;397:164-8. 
36 Sbisa E, Pesole G, Tullo A, Saccone C. The evolution of the RNase P- and RNase MRP-associated RNAs: phylogenetic analysis and nucleotide substitution rate. J Mol Evol 1996;43:46-57.

37 Cai T, Aulds J, Gill T, Cerio M, Schmitt ME. The Saccharomyces cerevisiae RNase mitochondrial RNA processing is critical for cell cycle progression at the end of mitosis. Genetics 2002;161:1029-42.

38 Jacobson MR, Cao LG, Wang YL, Pederson T. Dynamic localization of RNase MRP RNA in the nucleolus observed by fluorescent RNA biochemistry in living cells. J Cell Biol 1995;131:1649-58.

39 Horwitz EM, Prockop DJ, Fitspatrick LA. Transplantability and therapeutic effects of bone marrow-derived mesenchymal cells in children with osteogenesis imperfecta. Nature Med 1999:5:309-13.

40 Lajeunesse D, Busque L, Ménard P, Brunette MG, Bonny Y. Demonstration of an osteoblast defect in two cases of human malignant osteopetrosis. J Clin Invest 1996;98:1835-42.
41 Coccia PF, Krivit W, Cervenka J, Clawson C, Kersey JH, Kim TH, Nesbit ME, Ramsay NK, Warkentin PI, Teitelbaum SL, Kahn AJ, Brown DM. Successful bone marrow transplantation for infantile malignant osteopetrosis. N Engl J Med 1980;302:701-8.

42 Gerritsen EJ, Vossen JM, Fasth A, Friedrich W, Morgan G, Padmos A Vellodi A, Porras O, O'Meara A, Porta F, Bordigoni P, Cant A, Hermans J, Griscelli C, Fischer A. Bone marrow transplantation for autosomal recessive osteopetrosis. J Pediatr 1994;125:896-902.

43 Berthet F, Siegrist CA, Ozsahin H, Tuchschmid P, Eich G, Superti-Furga A Seger RA. Bone marrow transplantation in cartilage-hair hypoplasia: correction of the immunodeficiency but not of the chondrodysplasia. Eur J Pediatr 1996;55:286-90.

44 Bonafe L, Schmitt K, Eich G, Giedion A, Superti-Furga A. RMRP gene sequence analysis confirms a cartilage-hair hypoplasia variant with only skeletal manifestations and reveals a high density of single-nucleotide polymorphisms. Clin Genet 2002;61:146-1. 